\title{
The Influence of Pan-Slavic Ideologies on Kosovar School Texts: Implications for Diplomatic Relations with Turkey
}

\author{
BLERINA REXHA \\ University of Sydney \\ blerinarexha@gmail.com
}

\begin{abstract}
Historical works produced by Kosovars are currently at the centre of diplomatic concerns. Today Turkey is one of Kosovo's closest allies, but Turkish scholars and government officials are particularly critical of the way the history of the Ottoman Empire is being taught in Kosovo's schools. In this article I consider how Pan-Slavic ideologies have influenced the writing of Kosovar Albanian histories, particularly during theYugoslav socialist era. I draw on research concerning the relationship between bias in historical textbooks and international conflict. Exploring examples of historical literature currently being taught in Kosovo's primary and secondary schools, I analyse the discourses espoused by Kosovar historians in depicting the history of the Ottoman Empire. I argue that some of the Turkish criticisms are valid and hence there is need to revise historical texts used in Kosovo's schools. In particular, there is a need to provide more objective accounts of Kosovar Albanian history in classrooms, especially as regards anti-Ottomanism and the Pan-Slavism. The amendment of Kosovar historical texts in schools would not only provide students with a more accurate and informed interpretation of the past, but also contribute to efforts seeking to improve diplomatic relations.
\end{abstract}

\section{Introduction}

Since 2011, diplomatic controversy has surrounded the history books used by primary and secondary level students in Kosovo. At the forefront of the controversy is the way that Kosovo Albanian authors have portrayed the Ottoman Empire's almost fivecentury rule of the region. The Turkish foreign minister's visit in August 2011 to the fledgling nation-state evidently included the mission of requesting the removal from Kosovo textbooks of "loaded" language and offensive phrases in the depiction of the Ottoman Empire. Turkey is considered to be one of Kosovo's closest allies, Kosovo having signed numerous agreements with Turkey on military, economic and education matters. Turkey is one of the very few countries for which Kosovar nationals need no entry visa. In light of the positive diplomatic relations between the two nations, Kosovo's Ministry of Education immediately set up a committee to review Kosovo's textbooks and proposed changes in line with the requests made by Turkey. Much controversy has surrounded these proposed changes, which were due to appear in Kosovar textbooks by September 2013. However, amidst the controversy surrounding Turkey's request and the changes proposed by the Kosovars, there has been no investigation or discussion as to why the Ottoman Empire is portrayed negatively in Kosovo textbooks at all, especially given that Albanians are considered to have had a privileged status within the Ottoman Empire. 
The aim of this article is to discuss the influence of the Yugoslav Pan-Slavic ideologies on the negative sentiments of the Kosovo Albanian authors towards the Ottoman Empire's rule in Kosovo. Drawing on the research into bias in educational history texts, I discuss the Kosovar situation in comparison with comparable situations elsewhere.

\section{Kosovo's historical literacy and the global sphere}

Great importance is attached to the teaching of history in the schools of modern, developed nations. The instruction of history as a subject is often used as a means of perpetuating and transmitting the inherent ideals and values of national politics and history. ${ }^{1}$ Furthermore, history books produced and adopted in school curriculums have proven an obstacle to building friendly bilateral relations between nations in the past. Two countries that have dealt with issues concerning their history textbooks are Japan and Germany. In Japan, until the 1980s school textbooks toned down and even deleted some of the controversial topics of Japan's aggressive wartime history, especially of atrocities such as the Nanjing massacre. As a result of strong foreign criticism and internal change of educational policies, the Japanese government intervened in the writing and publication of its school text books as a means of protecting Japan's international reputation, and reconciliation with its Asian neighbours. ${ }^{2}$ Pressure from China and Korea caused the Japanese Ministry of Education to accept 'that textbooks must show understanding and international harmony in their treatment of modern and contemporary historical events involving neighbouring Asian countries'. ${ }^{3}$ However in 1994, the Japanese Society for History Textbook Reform, an ultra-conservative movement, proposed that changes to the history textbooks be reversed, and in 2001, they introduced a censored textbook titled: The New History Textbook which contained no mention of Japan's controversial topics. ${ }^{4}$ Although the textbook was approved by the Japanese Ministry of Education, the book was shunned by most Japanese districts, which have the authority to determine which textbooks are used in the school curriculum ${ }^{5}$.

In Germany's case, until the 1960s German school textbooks did not engage in reflections on German World War II crimes and the Holocaust. ${ }^{6}$ During the 1960 s an awareness of the lack of discussion on the Holocaust in history books began to take form as a result of scrutiny from Israel and the Jewish communities of Germany, Poland, France and elsewhere. ${ }^{7}$ The changes in German historians' attitudes towards a discussion of the Holocaust also arose from changes in German society and a rising awareness of Germany's past ${ }^{8}$. Unlike Japan, where the government was directly involved in the writing of history textbooks, in Germany independent institutions such as the Eckert-Institute acted as mediators between the societal consensus and state authorities to achieve historical accuracy and international reconciliation, which

\footnotetext{
${ }^{1}$ Georgeoff, J. (1966). "Nationalism in the History Textbooks of Yugoslavia and Bulgaria." Comparative Education Review, vol. 10, no. 3, p. 442.

${ }^{2}$ Saaler, S. (2005). Politics, Memory and Public Opinion: The History of Textbook Controversy and Japanese Society. Munich, Indicium Verlag, p. 6

3 Atsushi, M. (2001). “Abolish the Textbook Authorization System.” Japan Echo, vol. 28, p. 28.

4 Masalski, W., M. (2001). "Examinig the Japanese History Textbook Controversies." Stanford Program on International and Cross-Cultural Education, viewed 26 March 2013, http://spice.standford.edu/docs/124, p. 1 5 Ibid., p. 2

${ }^{6}$ Saaler, Politics, Memory, p. 2

7 Ibid., p. 2; Höpken, W. (2007). "Textbooks and Conflicts. Experiences from the Work of the Georg-EckertInstitute for International Textbook Research.” World Bank Website, 9 July 2007.

8 Saaler, Politics, Memory, p. 2.
} 
is generally acknowledged as a major objective of history education in Germany from the 1960's onwards. ${ }^{9}$

The way in which the history of the Ottoman Empire is written by Kosovar Albanian authors and utilised in primary and high school textbooks in Kosovo has had serious implications for Kosovo's relations with Turkey. Little attention has been paid by the Kosovar Ministry of Education to the portrayal of the Ottoman Empire in Kosovo history books. The national school curriculum of Kosovo consists mainly of history books either written during the Yugoslav era or after the 1999 Kosovo conflict. Those books written under the official Yugoslav regime were pan-Slavic in nature and reflected a negative stance towards the Ottoman Empire. By pan-Slavic I mean the ideology of Slav commonality throughout communist Eastern Europe and the aegis of Soviet socialism which is palpable in Kosovar Albanian texts. Moreover books written by Kosovar authors after the 1999 Kosovo war also present a negative view of the Ottoman Empire and a strongly nationalistic stance predicated on the rejection of the history of Ottoman imperialism.

During the Yugoslav communist era, Kosovo was heavily influenced by the official Yugoslav State ideology of Pan-Slavism which had been prevalent in the Balkan region for more than two centuries. ${ }^{10}$ At the time, most of the schoolbooks in Kosovo came from the neighbouring nation states, predominantly Serbia, and, as Murgescu argues, the textbooks did not reflect the Kosovar Albanians' own identity, vision or interests. ${ }^{11}$ Furthermore, the few books by Albanian authors that were published or recognised in Kosovo were written by authors who had been educated and controlled by Serbian authorities, who had adopted the official Yugoslav ideology and who expressed animosity towards the Ottomans in their writing. Under this strict regime, Albanian historians were restricted in their choice of subjects by the official canon of Yugoslav ideology. The Pan-Slavic influences on those Albanian authors educated in the Yugoslav regime are evident in the history books used by Kosovo Albanian students today, and will be discussed in more detail later. Furthermore, Kosovo school textbooks were heavily censored and from 1990 onwards, the teaching of history in Kosovo was 'Serbianised' and Serbian history replaced Albanian history. ${ }^{12}$

Indeed, the early 1990s marked a turning point in Kosovo's education system. In line with the political upheaval in Yugoslavia, this period also marked the beginning of 'significant and highly influential developments that have helped shape the planning and management of education in Kosovo. ${ }^{13}$ Earlier, in 1989, Yugoslavia's newly appointed leader at the time, Slobodan Milosevic, began to mount an effort to establish, or re-establish, the Serbianization, ${ }^{14}$ as a means of counteracting the perceived 'Albanization' of Kosovo. ${ }^{15}$ Along with establishing Serbian as the only official language to be used in the territory, Milosevic's regime also suspended the

\footnotetext{
9 Ibid., p. 6

${ }^{10}$ Ramet, S., P. (2002). "The Kingdom of God or the Kingdom of Ends: Kosovo in Serbian Perception". In Kosovo: Perceptions of War and Its Aftermath, edited by Buckley, M. and Cummings, S., N. N.Y.: Continium Press, p. 12. ${ }^{11}$ Murgescu, M-L. (2002). "Rewriting School Textbooks as a Tool of Understanding and Stability." Southeastern European and Black Sea Studies, vol. 2, no. 1, p. 94.

12 De Baets, A. (2002). "History: School Curricula and Textbooks.” In: Jones, D. (Ed.), Censorship: A World Encyclopaedia, Fitzroy Dearborn, London/Chicago, p. 2

13 Sommers, M. \& Bucklan, P. (2004). "Rebuilding the Education System in Kosovo." UNESCO Education in Emergencies and Reconstruction: Case Studies, http://www.unesco.org/iiep/PDF/pubs/kosovo.pdf, p. 41

${ }^{14}$ Bellamy, A., J. (2001). "Human Wrongs in Kosovo: 1974-1999.” In: Booth, K. (Ed.), The Kosovo Tragedy: The

Human Rights Dimensions. London; Portland, OR: Frank Cass, p. 114

${ }^{15}$ Sommers \& Bucklan (2004), p. 42.
} 
Provincial Parliament and Municipal Assemblies, with the result that all decisions on Kosovo came from Belgrade. In a bid to reduce the cultural and political autonomy of Albanians in Kosovo, the Milosevic government 'imposed a Serb curriculum in all higher education in Kosovo.' 'Most leading educational institutions, such as the University of Pristina, [were] purged on ethnic grounds. ${ }^{16}$ As a result, almost all Albanians were removed from public service, and Albanian was discontinued as a language of instruction. The separation of Albanian and Serbian students meant that the two groups could not attend school at the same time, and a single Serbianoriented curriculum was introduced, deeming as 'resigned' all the Albanian teachers who refused to teach it. ${ }^{17}$ In all, it is estimated that 14,500 primary and 4,000 secondary school teachers, and 862 university teachers of Albanian ethnicity were dismissed from schools during the early $1990 \mathrm{~s}$ in Kosovo. ${ }^{18}$

Although some Albanian primary school classes were conducted in the afternoon, after the Serbian classes were finished, all Albanian high schools were closed. In response, Kosovar Albanians set up a parallel education system whereby high school students would conduct their lessons in people's homes or empty store floors that were converted into classrooms. Teachers mostly worked on a voluntary basis, though they would sometimes receive a small symbolic allowance, either remittances from abroad, community money and in-kind donations, and informal tax revenues collected and managed at the municipality level. ${ }^{19}$ The curriculum taught at the time 'retained the same structure and textbooks for many subjects' which Serb and Albanian educators considered were the same. ${ }^{20}$ Although modifications were made, in particular to history subjects to include a stronger focus on Kosovo Albanian interpretations, by and large the curriculum retained the structure of the original curriculum studied before the introduction of the parallel structures. ${ }^{21}$ However beginning in 1990, the Kosovar textbooks, especially history textbooks, were developed by underground textbook operations which produced new textbooks and were smuggled into Kosovo from Albania. ${ }^{22}$ In addition, it is noted that although the curriculum of Kosovo was slightly modified during the early 1990s, it nevertheless 'largely retained the structure and pedagogical approach implicit in the original curriculum. ${ }^{23}$

The end of war did not bring about major changes to the Kosovar curriculum after 1999 , as 'schooling would commence based on the curriculum in use at each school immediately prior to the suspension of learning' and any catch-up classes that were conducted 'using the existing curriculum and textbooks. ${ }^{24}$ Therefore it can be said that the Albanian students in Kosovo were learning history with the textbooks produced during the Yugoslav regime or those produced by the Hoxha regime in

\footnotetext{
${ }^{16}$ Popa, A. (2010). “Kosovo Albanians Resist Serbian Rule, 1990-1998.” Global Nonviolent Action Database website, http://nvdatabase.swarthmore.edu/content/kosovo-albanians-resist-serbian-rule-1990-1998, p. 1.

${ }^{17}$ Alva, S., Murrugarra, E. \& Paci, P. (2002). "The Hidden Costs of Ethnic Conflict: Decomposing Trends in Educational Outcomes of Young Kosovars.” Policy Research Working Paper 2880 (August). World Bank, Washington, p. 7

${ }^{18}$ Leutloff, C. \& Pichl, E. (1999). “The State of Education in Kosovo After the Ceasefire in June 1999." In: Center for Study of Balkan Societies and Cultures: How to Construct civil societies? Education and Media in Southeast Europe: Country reports. Graz, p. 1.

${ }^{19}$ Sommers \& Bucklan (2004), p. 44.

${ }^{20}$ Ibid., p. 44

${ }^{21}$ Ibid., p. 86 .

${ }^{22}$ Clark (2000), p. 99.

${ }^{23}$ Sommers \& Bucklan (2004), p. 86

24 Sommers \& Bucklan (2004), pp. 86-87.
} 
Albania. Furthermore, those few textbooks which were produced by the underground book publishers shared the anti-Ottoman character of work published in Yugoslavia and Albania. As a result of schools, printing companies and storage facilities having been specifically targeted during the Kosovo war of 1999, Albanian language textbooks had been largely destroyed and there was an urgent need for textbooks at the recommencement of teaching immediately after the war. ${ }^{25}$ As a result, the United Nations Mission in Kosovo (UNMIK) was faced with the need for a quick solution, namely for schooling to 'commence based on the curriculum in use at each school immediately prior to the suspension of learning. ${ }^{26}$ These textbooks, totalling 130 titles, were reviewed by Kosovar educators and subsequently published and distributed during 1999/2000 under the supervision of UNMIK. However, large numbers of other textbooks not screened by UNMIK were also used in Kosovo . These textbooks had been shipped into Kosovo from Macedonia, Albanian, Bosnia and other countries. ${ }^{27}$

It was only during 2003 and 2004, that revisions of the Kosovar textbooks took place. Subject specialists drafted revisions in accordance with guidelines from the Albanian Ministry of Education. The drafting procedures were overseen by the curriculum and textbooks expert council of the Ministry of Education of Kosovo. The reviewer's role was to provide a critical evaluation of textbooks before their publication. The only international intervention in Kosovo's textbooks occurred in 2005, when the Leipzigbased German Georg-Eckert-Institut für internationale Schulbuchforschung (Georg Eckert Institute for International Textbook Research), which specialises in the field of education and the preparation of school curriculums, proposed a review of textbooks in the Balkan regions. The reviews however, never took place in Kosovo.

The alternative history books used in Kosovo were produced in Albania under the communist regime of Enver Hoxha. After the fall of Albanian communism in 1991 these books were reviewed and criticised for their ideological bias and hostility to the West. More recently attention has focused on their negative portrayal of the Ottoman Empire. In October 2009, Turkey's foreign minister, Ahmet Davutoğlu visited Tirana and stated that the Balkan countries and Turkey share "a common history, destiny and future." Davutoğlu's statement generated speculation in Albania, with Albanian government officials refusing to confirm or deny whether or not Davutoğlu had officially requested that Tirana revise the negative portrayal of the Ottoman Empire. ${ }^{28}$ Furthermore, after Davutoğlu's visit, in December of 2010 the German Albanologist, Peter Bartl, stated that Albania's history textbooks needed further revision as the Ottoman Empire should not be portrayed as a 'national tragedy' ${ }^{29}$ and as the 'darkest period of Albanian history. ${ }^{30}$

Davutoğlu's visit and Bartl's statements highlighted the issue of the portrayal of the Ottoman Empire in the history textbooks of the countries that were formerly a part of the Empire. As a result, a group of 60 historians from 11 southeast European countries were appointed by the Balkan Trust for Democracy for the purpose of revising regional history books and by September 2010, four new books were

\footnotetext{
25 Ibid., p. 86.

${ }^{26}$ Ibid.

${ }_{27}$ Daxner, M. (2000). "Education in Kosovo: From Crisis to Recovery and Transformation". Presented at the Graz

Stability Pact Meeting, 9-10 March 2000. Prishtina: UNMIK, p. 9.

${ }_{28}$ Hamidi (2010), p. 3-4

${ }^{29}$ Ibid., p. 1.

${ }^{30}$ Tema Online (2012)
} 
produced to be used by history teachers across the Balkans, however at present, none of these texts have been introduced in the Kosovo curriculum. ${ }^{31}$ Furthermore, Kosovo's independence has been questioned in the chronology of historical events of the first pages of the Nations and States in Southeast Europe book. The textbook does not include Kosovo as an independent nation, nor its flag or anthem. Contributing Kosovar Albanian authors Frashër Demaj, Jusuf Bajraktari and Fehmi Rexhepi are not mentioned in the list of 14 other contributing authors from other southeastern European countries. ${ }^{32}$

\section{The case of Kosovo's history textbooks}

In May 2011, the Turkish Minister of Education, Omer Dinçer, visited Kosovo and requested that the Kosovo Ministry of Education revise those parts of the official history textbooks covering the Ottoman rule in Kosovo. Dinçer referred to preuniversity level textbooks used by Kosovar students in the Albanian, Bosnian and Turkish languages, and presented the Kosovar Ministry of Education with a comprehensive report on all words and phrases which the Turkish Embassy in Kosovo preferred to be 'mitigated, reconsidered, reformulated, specified, eliminated, or removed of any professional scientific error. ${ }^{33}$ The Turkish Embassy claimed that the textbooks contained negative and loaded language in regard to Turkey and the Ottomans, and stressed the removal of words and phrases such as: 'barbaric', 'wild', 'invasion', 'violence', 'murder', 'blood tribute' and 'slavery.' The situation is further complicated as contemporary Kosovar authors of history textbooks appear to have failed to make a clear distinction between Ottomans and modern day Turks. This may be seen as the basis for a significant negative impact on Kosovar students' perception of Turkey and its people. During a subsequent visit to Kosovo in August 2011, Turkish Foreign Minister Davutoğlu stated that 'Kosovar historians should free themselves of the Cold War and ideological historiography. ${ }^{, 34}$

After Dinçer's visit, Kosovo's education minister, Ramë Buja, appointed a special committee to "review the presentation of history, geography and culture in relation to the Ottoman Turks in Kosovar pre-university level textbooks." ${ }^{35}$ Nevertheless, the request from Dinçer was not well received by the Kosovo media, and news articles were published with titles such as: 'Turkish Minister Wants to Change History, ${ }^{36}$ and 'Prishtina Told to Revise History Books. ${ }^{37}$

Following the Turkish requests, in 2012 Kosovo's Ministry of Education conducted an analysis of textbooks published before and after 1999 to compare the differences in

\footnotetext{
${ }^{31}$ Erebara (2010), p. 3

32 “Turqia interesohet për trajtimin e Perandorisë Osmane në Kosovë.” Koha.net. 11 Mar 2013. http://koha.net/?page $=1,13,138186$

${ }^{33}$ Rexha, A., Mehmeti, A. and Drançolli, A. (2011). "The Image of the Ottoman Empire in History Textbook of the Republic of Kosova." Conference paper presented at the International Symposium on the Ottoman Legacy in the Balkans.

${ }^{34}$ Türbedar, E. (2011). “Turkey's New Activism in the Western Balkans: Ambitions and Obstacles.” Insight

Turkey, vol. 13 , no. 3, p. 1 .

35 “Turqia kërkon ndryshime në tekstet e historisë në Kosovë: Janë fyese.” Tema Oline. 20 Aug 2011.

http://www.gazetatema.net/web/2011/o8/20/turqia-kerkon-ndryshime-ne-tekstet-e-historise-ne-kosove-janefyese/

36“Ministri Turk kërkon ndryshimin e historisë.” Gjuhashqipe.net. 19 Aug 2011. http://www.gjuhashqipe.com/lajmetari/lajmetari2.aspx?id=12167

${ }^{37}$ Hamidi, L. (2010). "Prishtina 'Told to Revise History Books."' Balkan Insight,

http://www.balkaninsight.com/en/article/pristina-told-to-revise-history-books.
} 
the presentation of the Ottoman Empire. (After 1999 Albanian authors in Kosovo were able to publish books without interference from the Serbian regime.) According to the report, those textbooks published before 1999 showed that traditional communist attitudes and perspectives that were prevalent in Yugoslav textbooks were also evident in certain school textbooks of Kosovo. According to Drancolli et al this is the language of instrumentalized history, depicting the Ottoman occupation in emotive and exaggerated terminology in order to support the policies of the regimes of the time. ${ }^{, 38}$ The use of loaded language to negatively portray the Ottoman Empire was present in almost every history textbook, depicting the Ottoman Empire as a 'severe conqueror' and holding them accountable for the stagnation of Albanian society. ${ }^{39}$

Furthermore, the Kosovo textbooks also shared terminology with the Serbian textbooks, by referring to the Ottoman Empire as 'Turks'. Whilst the language used in Kosovar textbooks to portray the Ottoman Empire could indeed be considered as being 'loaded', and unsuitable for study by young students, the committee's report was a tokenistic response to the Turkish request for change. The Kosovar committee did not engage with the textbooks authors or engage in debate with historians regarding the proposed changes; nor did they take into account the reasons as to why loaded language was used by the Kosovar authors. Furthermore, the Kosovar committee failed to recognize that the textbooks did not highlight the positive aspects of the Ottoman Empire in Kosovo as proposed by the Turks; rather their focus was mainly on the military and political aspects of the Ottoman state, 'leaving very little space for the social, cultural and religious colors of the empire. ${ }^{, 40}$

\section{The history of Kosovo's education system}

During the Yugoslav era, Kosovo shared the education programs of the other Yugoslav states. Although schools for Albanians existed prior to 1941, the teaching was only conducted in Serbian and Turkish, due to the limited number of Albanian teachers available. In 1942 the first high schools for Albanians opened in Kosovo, and in 1953 the first Albanian language college opened in Belgrade, where Serbian professors taught history and the students trained at these schools would return to teach in Kosovo. From 1945 to 1967, all texts used by Albanian students in Kosovo had been written by Serbian authors and translated into Albanian. Furthermore, Shatri states that the majority of these textbooks were originally written in Russian by Russian authors, but had been translated into Serbian to be used in Yugoslavia. ${ }^{41}$ These textbooks which were used by Kosovar students did not discuss Albanian historical figures such as Skanderbeg, Ismail Qemail, Isa Boletin, Hasan Prishtina, and others. The Kosovar Albanian students who studied those textbooks learned about ancient, middle age and modern Serbian histories, and the textbooks contained 'untruths and were offensive to the Albanian people. ${ }^{42}$ Although during the 1970 s the Kosovar Albanians gained increased control of the education system, autonomy at the school level was limited. In 1967 the first history book written by the Kosovar Albanian Ali Hadri was produced, proving to be highly popular not only amongst

\footnotetext{
${ }^{38}$ Rexha et. al. (2011), p. 1.

${ }^{39}$ Ibid., p. 1.

${ }^{40}$ Türbedar (2011), p. 2.

${ }^{41}$ Shatri, B. (2006). Arsimi Fillor në Kosovë në Shekullin XX. Sfida, dëshmi, fakte II. Prishtinë, Shtëpia Botuese Libri Shkollor, p. 919.

$4^{2}$ Ibid., p. 918.
} 
primary level students, but also high school students and the general Albanian public in Kosovo. ${ }^{43}$ However, Serbian history would continue to dominate Albanian history books, as Shatri states that Hadri's textbook: 'was only a supplementary text for Albanian history, and the Serbian authored texts continued to be used as the main textbook. ${ }^{44}$ Although Albanian authors did enjoy a certain degree of autonomy in writing, Sommers and Bucklan agree that the Yugoslav states' 'central control and coherence were maintained largely through a system of centrally determined 'norms' that applied to virtually every aspect of education. ${ }^{, 45}$

The common socialist educational system which was in place in all of the former Yugoslav countries for more than four decades had a strong impact on the way history is taught at schools today. ${ }^{46}$ The specific features of history taught in the former Yugoslav countries, namely the fostering of resentment and victimisation, have transcended the national borders, and are even today found in many of the southeast European countries and are considered to be the most problematic aspect of history teaching in the Balkans ${ }^{47}$ Hajdarpašic posits that this is the influence of the nineteenth-century Balkan nationalist movements which perceived the Ottoman Empire as 'a religiously, socially, and institutionally alien imposition on autochthonous Christian medieval societies ... The central element of this interpretation is the belief in the incompatibility between Christianity and Islam, between the essentially nomadic civilization of the newcomers and the ... settled agrarian civilizations of the Balkans and the Middle East. ${ }^{48}$ It was as a result of these divisions that the non-Muslim inhabitants of the Balkans experienced discrimination, as many were over-taxed, were exposed to abuse by local Muslim notables, which 'provided ample grounds for the mobilization of uprisings and nationalist grievances against the Ottoman misrule throughout the nineteenth century. ${ }^{49}$

In particular, Pan-Slavism would continue to play a significant role in Yugoslavia, with the formation of a Pan-Slav club in Belgrade in 1948-9. ${ }^{50}$ The club issued a call for a general rising of all Ottoman South Slavs and aimed at establishing a 'Yugo' state headed by Alexander. ${ }^{51}$ Analysis of popular Serbian history books from the late $19^{\text {th }}$ and early $20^{\text {th }}$ century reveals loaded language in the description of the Ottoman history of the region. The most commonly used negative expressions in the Serbianpublished Kosovar textbooks include: 'Egër' (wild), 'Barbar' (barbaric), 'Terror' (terror), 'Robëri' (slavery) and 'Plaçkitje' (plunder). Bogosavljević's book of 1897 titled: O Arnautima (On Arnauts), Vladan Đorđević's Arnauti I Velike Sile (Arnauts (Albanians) and Great Powers) of 1913, Stojan Protić's Albanski problem I Srbija I Austro-Ugarska (Arnautski Problem in Serbia and Austro-Hungary, 1913) and Jovan Tomić's Prepiska o Arbanaskim Nasiljima u Staroj Srbiji (Correspondence about Albanian Violence in Old Serbia), 1898-1899, 1899) also make use of these expressions. In his Serbian history of 1909 Dr. Jovan Hadzi Vasijlevic writes, for example:

43 Ibid., p. 923

44 Ibid., p. 923

45 Sommers \& Bucklan (2004), p. 100.

46 Sicurella (2008), p. 11.

47 Ibid, p. 11, 16

${ }^{48}$ Hajdarpašić, E. (2008). "Out of the Ruins of the Ottoman Empire: Reflections on the Ottoman Legacy in South-

Eastern Europe." Middle Eastern Studies, vol. 44, no. 5, p. 717.

49 Ibid., p. 717-718.

${ }^{5}$ Hupckick, D. (2002). The Balkans: From Constantinople to Communism. New York, Palgrave Macmillan., p.

218

${ }^{51}$ Ibid., p. 218. 
Deli Aguš, along with ten other terrorists went to the village elder and attacked him in his home, causing him the most terrible suffering, pulling his beard with pliers and poking his body with a knife while exhorting him to bear the pain. They took from the old man 10,000 groshen [a monetary unit of the Ottoman Empire] and looted all that they could find in the house $[\ldots]^{52}$

During the early $20^{\text {th }}$ century in Yugoslavia, the reiteration of the anti-Ottoman ideology would be carried out by 'authoritative writers and scholars [who] helped extend the dominance of this [anti-Ottoman] narrative. ${ }^{53}$ One such prominent writer was Ivo Andrić, who wrote in his 1924 doctoral thesis on the history of the Ottoman rule in Bosnia, that the Turks, 'an Asiatic military people [...] shackled the life of the spirit and the mind in Bosnia. ${ }^{54}$ In his widely available work, which was originally written in German, translated into, and published in Serbo-Croatian in 1982, Andrić writes of the four centuries of Ottoman rule, 'the Turks could bring no cultural content or sense of higher historic mission, even to those South Slavs who accepted Islam; for their Christian subjects, their hegemony [...] meant a step to the rear in every respect. ${ }^{, 55}$

Although Andrić's thesis became widely available only in the early 1980s, 'the perspectives that he adopted from the nineteenth-century nationalist writers continued to broadly circulate throughout the twentieth century because of his uncontested status as an insightful, brilliant writer. ${ }^{56}$ Yugoslav scholars uncritically accepted the writer's dissertation as 'the genesis of all that Andric as a literary author created' and as 'another illuminating contribution made by one of the greatest writers of the twentieth century. ${ }^{57}$ Andrićs prominence grew in 1961, when he won the Nobel Prize in Literature for the novel titled Bridge over the Drina, which portrays the Ottoman Empire in a negative light.

Furthermore in Yugoslavia, even those Croatian authors, namely Andrija KačićMiošić, Matija A. Reljković, and Ivan Mažuranić who had written works with an antiTurkish theme, were widely quoted. ${ }^{58}$ Jelavich states that even a major-general in the Habsburg army, Petar Preradović, was viewed favourably by the Yugoslav government for his drama titled Krajlević Marko. ${ }^{59}$ Although Croatian, these authors were accepted 'because their nationalist, romantic, anti-Ottoman writings shared the literary heritage of nineteenth-century Serbian literature. ${ }^{60}$ Furthermore, students reading the works of these authors would assume that they were Serbian, unless the teacher specifically stated they were Croatian authors, ${ }^{61}$ which shows the impact of Pan-Slavist ideology even on a predominantly catholic country like Croatia.

\footnotetext{
${ }^{52}$ Vasiljević, J. H. (1909). “Kumanovska oblast.” Južna stara Srbija: Istorïjska, et nografska i politička istraživanja. Belgrade, p. 217. (Trans BR.)

${ }^{53}$ Hajrdarpašič (2008), p. 719.

${ }^{54}$ Ibid., p. 719.

${ }^{55}$ Andrić, I. (1991). The Development of Spiritual Life in Bosnia Under the Influence of Turkish Rule. Durham.

Duke University Press, p. 16-17.

${ }^{56}$ Hajrdarpašič ( 2008), p. 719 .

${ }^{57}$ Konstantinović, Z. (1982). “O Andrićevom doktoratu: Pogocor uz disertaciju Ive Andrića.” Sveske zadužbine Ive Andrića, vol 1, p. 274-5.

${ }^{58}$ Jelavich, C. (1983). "Serbian Textbooks: Toward Greater Serbia or Yugoslavia?” Slavic Review, vol. 42, no. 4, p. 614 .

${ }^{59}$ Ibid., p. 614

${ }^{60}$ Ibid., p. 614 .

${ }^{61}$ Ibid., p. 614 .
} 


\section{The content of Kosovo's textbooks}

The Turkish Education Minister's request to Kosovo's Ministry of Education to review and alter aspects of the Kosovar textbooks referred specifically to preuniversity level textbooks used by Kosovar students in the Albanian, Bosnian and Turkish languages. Imer Dinçer, Turkey's Education Minister, presented the Kosovar Ministry of Education with a comprehensive report on all words and phrases which the Turkish Embassy in Kosovo preferred to be 'mitigated, reconsidered, reformulated, specified, eliminated, or removed of any professional scientific error. ${ }^{62}$ The Turkish Ministry of Education claimed that the Kosovo textbooks in question contain 'hateful' language towards Turkey, ${ }^{63}$ and stressed the removal of words, in particular the following words which are used more commonly than others: 'barbaric', 'plunder', 'wild', 'invasion', 'violence', 'murder', 'blood tribute' and 'slavery'; amongst others.

The Turkish report provides a detailed description of some of the most commonly used words and phrases and their contextual settings in the Kosovo textbooks. Analysis of the disputed language is followed by the recommendation of proposed changes by the committee from Kosovo's Ministry of Education. The word 'barbarian' appears in a grade 10 old Albanian literature textbook, in the following paragraph:

After (Skanderbeg) returned to the soldiers, he said: "soldiers, go towards the enemy and tell them that I am also coming", some horsemen went outside the city and...met the barbarian army. When the barbarians saw that Skanderbeg was approaching, they fled the already heavily looted area (Hamiti 2004, p. 103).

However the report from the Kosovo review committee recommends no change to this paragraph, without providing any justification.

'Plunder' appears in a grade 5 history textbook, in the following form:

In 1371 a few Balkan princes joined in the resistance to the Ottoman armies. Also among these princes was Alexander, the head chief of Vlora. In the battle of Marica of Bulgaria, the prince's army was defeated and so the attacks and plundering by the Ottomans of the Balkan countries continued (Demaj \& Rexhepi 2007, p. 33).

The proposed change by the Kosovars to this paragraph is: the prince's army was defeated and the Ottoman army later occupied some other Balkan states.

'Wild' appears in a grade 11 history textbook:

In the late nineteenth century Albanians were still faced with the wild Ottoman rule. (Demaj \& Rexhepi 2004, p. 83)

The proposed change to this phrase is 'Ottoman invasion' instead of 'Wild Ottoman rule'. Similarly, the word 'terror' was also used in a grade 11 history textbook:

\footnotetext{
${ }^{62}$ Raça, Sh., Pllana, R., Matoshi, H., Mustafa, A. \& Rexha. A. (2011). "Raport nga: komisioni pë rishikimin e prezantimit të historisë, gjeografisë dhe kulturës osmane e turke në tekstet shkollore në Republikën e Kosovës." Republika e Kosoves, Ministria e Arsimit, Shkencës dhe Teknologjisë. Prishtinë ${ }^{63}$ Ibid.
} 
Ottoman forces dispersed the League of Prizren and the Albanian Provisional Government and exercised unprecedented terror in Kosovo (Demaj \& Rexhepi 2004, p. 35).

The Kosovar committee, however, proposed that no changes should be made to this paragraph.

The words 'violence' and 'murder' are common in Kosovar textbooks and are cited numerous times by the Turkish side. One example where the Kosovar committee proposed 'violence' to be substituted with 'invasion' and 'murder' with 'imprisonment' is:

Due to the Ottoman violence, Albanian exiles helped their country; even from the countries where they lived...they published books and magazines. The Ottoman government feared the education of Albanians. For this reason Albanian intellectuals and patriots were hounded and murdered (Demaj \& Rexhepi 2007, p. 62).

The Kosovar authors of this paragraph refer to the Ottoman treatment of Albanian authors such as Adbyl Frashëri, member of the League of Prizren who was arrested and sentenced to death by the Ottomans. Although his sentence was reduced to life in prison, he died after spending three years in prison due to ill health resulting from his imprisonment. According to Malcolm ${ }^{64}$, at the same time under Dervish Pasha, 4000 Albanians were arrested and deported to Asia Minor, and Sulejman Vokshi, another prominent nationalist Albanian leader, was sentenced to death.

Other words cited by the Turkish report are 'blood tribute', to which no change was proposed by the Kosovar committee:

Blood tribute was a heavy duty. The central Ottoman government in certain circumstances garnered Christian sons, who after the appropriate religious education in the Royal Military ranks, entered the Janissary Corps (Abdyli \& Bakalli 2004, p. 35)

Another commonly used word is 'slavery', and it appears in a grade 12 history textbook:

The armed movement aimed at not only educating the people but also liberating them from Ottoman slavery (Bajraktari \& Salihu 2005, p. 69).

The Kosovar committee proposed to remove 'slavery' and substitute it with 'Ottoman domination'. However, according to numerous authors on Kosovar history, slavery did indeed exist under the Ottoman Empire. The authors of the above paragraph imply that the entire Ottoman rule in Kosovo was one of slavery, which Malcolm argues is untrue; however most Balkan countries emphasise the slavery prevalent during Ottoman rule.

Other words which the Turkish authorities requested to be used instead of 'invasion' are 'stretch' or 'extension. ${ }^{, 65}$ In addition, phrases which the Turks have asked to be

64 Malcolm (1998), p. 227

${ }^{65}$ Raça, Sh., Pllana, R., Matoshi, H., Mustafa, A. \& Rexha. A. (2011). "Raport nga: komisioni pë rishikimin e prezantimit të historisë, gjeografisë dhe kulturës osmane e turke në tekstet shkollore në Republikën e Kosovës." Republika e Kosoves, Ministria e Arsimit, Shkencës dhe Teknologjisë. Prishtinë 
revised, claiming that 'they are not suitable for Turkey, ${ }^{, 66}$ are 'imposition of religion', 'they ruled us for 500 years', as well as the glorification of Milos Kopiliç as a hero who killed Sultan Murat at the Battle of Kosovo. Furthermore, Turkish authorities asked for the discussion of the exhumation of Pjeter Bogdani, found in a grade 7 reading and comprehension textbook, to be avoided in texts other than those concerning history. ${ }^{67}$

In response to the Turkish request, Kosovo's Chairman of the Review Commission, Dr. Shkelzen Raça, stated that 'Kosovo has a moral obligation to Ottoman culture in the textbooks of Kosovo, to review, giving priority to eventual concessions, without removing historical facts. ${ }^{, 68}$ Further proposed changes by the review commission included that a distinction to be made between 'Ottoman Empire', 'Ottoman', 'Turk', and 'Turkey', in order to 'respect the historical context of the state organization. ${ }^{69}$ For the same reason the committee proposed that 'Turk' or 'Turkey', be replaced with 'Ottoman' and 'Ottoman Empire', and in future textbooks, the committee proposed 'the careful determination of correct terminology, in view of the existing political and historical realities of the past, whilst also considering all the ethnic minorities in Kosovo. ${ }^{70}$

In what can be viewed as an attempt by Turkey to legitimize their request to Kosovo, it is stated in the Kosovar report that during their delegation's visit to Turkey, the Kosovars had been advised that Turkish historians had also entered into talks with other countries, such as Greece, 'with the aim of alleviating and eliminating emotionally charged or offensive terminology, which could damage relations between the two countries. ${ }^{71}$ The request made by Turkey is in line with their 'more sophisticated and better coordinated' reorientation towards the Balkan regions, which 'aims to initiate a psychological breakthrough in the Balkans to undo the negative memories of the past. ${ }^{, 72}$ Turkey sees the 'bitter history' in the Balkans as a 'psychological barrier' and a 'major challenge' to the 'cooperative Turkish policy toward the Balkans', which 'stand in the way of the bilateral and multilateral mechanisms. ${ }^{73}$ Through the minimization of problems within the Balkan regions, Turkey aims to 'develop economic and political relations to the highest level of integration' and they see this as an essential component of their new regional policy for stability in the Balkans and at home. ${ }^{74}$

Following the Turkish request, Kosovo claimed to have already begun to review and partially re-evaluate the textbooks, with the aim of 'raising their quality by eradicating emotive language of ethnic identification. ${ }^{75}$ The final report of the Kosovo Ministry of Education proposes the necessary amendments to their textbooks in respect for the observations of the Kosovo review committee and the guidelines of the Eckert Institute, which in 2005 advised countries of the Balkan region to review

\footnotetext{
${ }^{66}$ Ibid.

${ }^{67}$ Ibid.

${ }^{68}$ Ibid.

${ }^{69}$ Ibid., p. 61.

${ }^{70}$ Ibid., p. 63

${ }^{71}$ Ibid., p. 8

${ }^{72}$ Aras, B. (2012). "Turkey and the Balkans: New Policy in a Changing Regional Environment." On Turkey. The German Marshal Fund of the United States, p. 1.

${ }^{73}$ Ibid., p. 1.

${ }^{74}$ Aras (2012), p. 1.

${ }^{75}$ Rexha, A., Mehmeti, A. and Drançolli, A. (2011). "The Image of the Ottoman Empire in History Textbook of the Republic of Kosova." Presented at the International Symposium on the Ottoman Legacy in the Balkans.
} 
their textbooks. Kosovo's Review Commission stated that most of the Turkish government's requested changes would not be made, as they were drawn 'from Albanian literature, and any change to them would be deemed as censorship. ${ }^{.76}$ In fact, however, ninety percent of the Turkish requests were met. In addition, they stated that these books needed to be corrected, as many of them had been studied for decades and yet were riddled with errors.

The review committee acknowledged the fact that Kosovo had not yet passed the post-conflict phase, but pointed out that as textbooks for the future were to be produced, authors, experts and reviewers should organize interdisciplinary discussions to ensure their improved educational value ${ }^{77}$ The report concludes by stating that the textbooks should emphasise aspects which bring Kosovo and Turkey together, stressing the positive aspects of Albanian-Turk relations in the past and that history should be written in a language that promotes co-operation, tolerance and reference to the values of the exchange of experiences of history and culture. ${ }^{78}$ The Kosovo review committee thereby tacitly accepted that political issues would continue to influence the writing of history in Kosovo.

Kosovo's Ministry of Education stated at the time that the amended textbooks would be introduced into the school curriculum from September $2013,{ }^{79}$ and that in the meantime, the Turkish government planned to send a delegation to Kosovo at the end of March 2013 to discuss the coverage of the Ottoman Empire in Kosovar history texts, 'to look at some of the suggestions given by the Kosovo experts, and organize debates on the issue. ${ }^{, 80}$ In light of the controversy caused by the Turkish delegation's planned visit, Nehat Mustafa, Kosovo's deputy Minister of Education, stated that the proposed changes would be made" so that our texts have less hate," and that the Kosovo Ministry of Education had also communicated with countries other than Turkey in relation to the emendation of textbooks. ${ }^{81}$

The Kosovo Albanian authors of the history books in question viewed the Turkish visit as a means of applying pressure on authors to make the proposed changes, with Frashër Demaj, a prominent Kosovar historian and author, affirming his independence from the government, and refusing to recognise any commission that attempts to interfere in scholarly issues. ${ }^{82}$ Demaj also highlighted the lack of communication between Kosovo's Ministry of Education and the Kosovar textbook authors to be affected by the proposed changes, stressing that the authors had not even been given a copy of the commission's report for suggested changes, nor had there been any initiative by the Ministry of Education to organize a meeting with the affected authors. In light of this, Kosovo's Education Minister, Ramë Buja stated that an open debate would be held with relevant experts, followed by meetings with the

\footnotetext{
${ }^{76}$ Raça, Sh., Pllana, R., Matoshi, H., Mustafa, A. \& Rexha. A. (2011). "Raport nga: komisioni pë rishikimin e prezantimit të historisë, gjeografisë dhe kulturës osmane e turke në tekstet shkollore në Republikën e Kosovës." Republika e Kosoves, Ministria e Arsimit, Shkencës dhe Teknologjisë. Prishtinë, p. 6

${ }^{77}$ Rexha, A., Mehmeti, A. and Drançolli, A. (2011). "The Image of the Ottoman Empire in History Textbook of the Republic of Kosova." Presented at the International Symposium on the Ottoman Legacy in the Balkans. ${ }^{78}$ Ibid.

${ }^{79}$ Musliu, J. (2013). “Kosovo Textbooks Soften Line on Ottoman Rule.” Balkan Insight, viewed 26 March 2013 , http://www.balkaninsight.com/en/article/kosovo-textbooks-soften-line-on-Ottoman 80"Vazhdon procesi i rishikimit të teksteve të historisë.” Zeri.info. 27 Mar 2013. http://www.zeri.info/artikulli/581/vazhdon-procesi-i-rishikimit-te-teksteve-te-historise. ${ }^{81}$ Ibid.

82 “Turqia interesohet për trajtimin e Perandorisë Osmane në Kosovë.” Koha.net. 11 Mar 2013. http://koha.net/?page=1,13,138186, p. 1 .
} 
affected textbook authors, so that the commission's recommendations might be discussed. ${ }^{83}$

The controversy surrounding the amendment of Kosovar textbooks continues in the wake of March 2013, when a large number of Albanian intellectuals, among them the renowned Albanian writer Ismail Kadare, signed and sent a petition to the two leaders of the Albanian states (to Kosovo's president Ahtifete Jahjaga and Albania's president Bujar Nishani) stating that the Ottoman occupation caused a 'black hole' in Albanian history and that it interrupted normal historical processes of the development' of the Albanian nation. ${ }^{84}$ The petition requested the two Albanian leaders to "nullify the work of the joint committee to review the history of the Albanian state and allow historians to work independently, according to the principles and methodology of historical science and not according to the interests and political orders of Turkey's current government. ${ }^{85}$

\section{Pan-Slavism in Yugoslav textbooks}

Anti-Ottoman Pan-Slavic ideological material was carried over into the MarxistLeninist framework of the Yugoslav education system, where history became a "means for inculcating a deep and stirring patriotism. ${ }^{86}$ As Georgeoff argues in his analysis of history textbooks used in the former Yugoslavia, 'many Turkish atrocities are described; and the anti-Turkish revolutionary movements of each nation are emphasized. ${ }^{87}$ Pesic agrees that the Turks are presented as an enemy in Serbian texts ${ }^{88}$ and moreover, these 'patriotically oriented 'historians' are more popular and more influential than those scholars whose much more objective historical writings have only a marginal impact. ${ }^{, 89}$ Similarly, Hajdarpašić's analysis of history books used in Bosnia prior to the reforms show a 'nationalist stunt [that] clearly relies on the familiar images of 'the Turkish yoke' - especially on the image of the brutal Ottoman practice of child-levying (or devşirme). ${ }^{90}$

The Yugoslav education system shared the aim of other socialist education systems, attempting to instill a 'socialist morale' into the people, willing to 'embrace all the contents and the aims of education with socialist ideology, with the aim of preparing young generations to conform to a framework. ${ }^{91}$ Furthermore, Sicurella states that the Yugoslav federation's socialist education agenda was enmeshed with the political doctrine of 'brotherhood and unity', in order to ensure the "accommodation and the 'neutralisation' of the different national interests within the federation." ${ }^{\prime 2}$ So great was the influence of this 'brotherhood and unity' idea in the writing of history books

83 Ibid., p. 1.

84 Konti, I. (2013). “Rishikimi I historisë, intelektualët peticion kundër vendimit.” Albania Observer website. 27

Mar 2013. http://www.alb-observer.com/2013/o3/rishikimi-i-historise-intelektualet-peticion-kunder-vendimit/. 85 Ibid.

${ }^{86}$ Georgeoff (1966), p. 442.

${ }^{87}$ Ibid., p. 443.

${ }^{88}$ Pešić, V. (1994). "Bellicose Virtues in Elementary School Readers." In Pešić, V. \& Rosandić, R. (Ed.) Warfare, patriotism, patriarch: the analysis of elementary textbooks. Belgrade, Centre for Anti-War Action, p. 65.

${ }^{89}$ Dimitras (2000), p. 44.

${ }^{90}$ Hajdarpašić (2008), p. 716 .

${ }^{91}$ Sicurella (2008), p. 12.

${ }_{92}$ Ibid., p. 12. 
in Yugoslavia, that the inter-ethnic rivalry was seen as a 'bourgois' feature, considered to have disappeared under communism. ${ }^{93}$

Türbedar notes that the negative portrayal of the Ottomans, was mostly evident 'during the communist era, when textbooks were used to serve the purposes of political establishment, its policies and ideologies' as was evident in the analysis of textbooks earlier. ${ }^{94}$ Furthermore, these histories of the 'corporate entities' that suffered centuries of oppression under 'Turkish' imperial rule, 'continue to be used consciously by post-Ottoman regimes to craft a sense of national identity defined as the antithesis of everything 'Turkish. ${ }^{, 95}$ Particularly for the Kosovo Albanians, the biased representation of the Ottoman Empire and the 'rhetorical references to national misfortunes suffered under the Ottomans' serve to 'nurture resentment of past injustices, mobilize support for extreme positions, and silence debate about present-day political choices ${ }^{96}$ which could be an obstacle to the diplomatic relations of Kosovo with Turkey.

Kosovo's history books share the common narrative pattern of Yugoslav history texts in 'lingering over memories of collective wrongs and cruelties suffered from another national or ethnic groups, which loads present-day classes with resentment and makes them appear as a re-dress. ${ }^{97}$ As Stojanovic has shown, the former Yugoslav history books depict their country as being the target of unremitting territorial aspirations by neighbouring countries, which further reinforces the country's selfperception as a 'historical victim' and heightens its fear of neighbouring nations. ${ }^{98}$ Indeed, Sicurella concludes that 'the fostering of resentment and victimisation is probably the most problematic aspect of history teaching in the Balkans. ${ }^{99}$ Similarly, Albania's textbooks under communism also portrayed the Ottoman Empire "in an extremely negative way by unreasonably emphasising ... underdevelopment, subjugation and the violence used by the Ottomans and by defining the period simply by the popular uprising against the Ottoman rule'. ${ }^{100}$

\section{Alternative Kosovar representations of Ottoman history}

The negative portrayal of the Ottoman Empire's domination of the Kosovar Albanians is contested. Prominent non-Albanian scholar Peter Bartl argues that Albanians need not present the Ottoman Empire so negatively. Similarly historian Dennis D. Hupchick states that 'there were no conditions in the Ottoman era to necessitate a general Albanian uprising. ${ }^{, 01}$ Renowned Balkan specialist Noel Malcolm contends that it was indeed the Albanians abroad who, before 1878, were aiming to establish an independent Albanian state, and not the Albanians within the Empire. The

\footnotetext{
${ }^{93}$ Höpken, W. (1996). "History Education and Yugoslav (Dis-)Integration.” In Höpken, W. (Ed.) Oil in Fire? Textbooks, Stereotypes, and Violence in Southeastern Europe. Hannover, Verlag Hahnsche Buchhandlung ${ }_{94}^{94}$ Türbedar (2011), p.1

${ }^{95}$ Anscombe, F. F. (2006). "The Ottoman Empire in recent International Politics - II: the case of Kosovo.

International History Review, vol. 28, no. 4, p. 758.

${ }^{96}$ Ibid, p. 758.

${ }^{97}$ Jedlicki, J. (1999). "Historical memory as a source of conflicts in Eastern Europe." Communist Post-Communist Studies, Pp. 225-232.

${ }^{98}$ Stojanović, D. (2001). "History Books and the creation of National Identity." In Koulouri, C. (Ed.) Teaching the History of Southeastern Europe. Thessaloniki, Petros Th. Ballidis \& Co., p. 27-32.

${ }^{99}$ Sicurella (2008). p. 16.

${ }^{100}$ Erebara (2010), p. 3.

${ }^{101}$ Türbedar, E. (2011). "Turkey's New Activism in the Western Balkans: Ambitions and Obstacles." Insight

Turkey, vol. 13, no. 3, p. 1 .
} 
emergence of the anti-Ottoman and Turkish elements in Albanian history books came about as a result of the 'shaping of a western Albanian identity' which occurred during the process of building a modern Albanian state, and at that time 'Albanians started writing their history so as to gloss over its Ottoman past. ${ }^{102}$

Indeed the view that the Albanians had a privileged status within the Ottoman Empire was expressed by Sami Frashëri, brother of Abdyl Frashëri (founder of the League of Prizren), a highly respected poet and newspaper editor in Istanbul during the late $19^{\text {th }}$ century. In his book titled: Shqipëria - Ç'ka qënë, ç'është e ç'do të bëhetë? (Albania - What it was, What it is and What will become of it), first published in 1899, Sami Frashëri set out the three major periods in which the standing of Albanians in the Ottoman Empire significantly differed. ${ }^{103}$ The first period, from 1443 to 1468 when Skanderbeg successfully fought against the Ottoman Empire, is also considered by Frashëri as the period during which the Albanians were 'guardians of Europe' from the advance of the Ottomans. As Frashëri writes: 'All European governments of that time had hope on Skanderbeg and expected to be rescued by the Albanians. ${ }^{104}$ Frashëri characterizes the second period, from the time of Skanderbeg's death in 1468 until the middle of the $19^{\text {th }}$ century, as the period during which Albanians became integrated as part of the Ottoman Empire. According to Frashëri, during this period 'Albanians became richer than ever, and Albanians progressed within the ranks of the Ottoman government, including more than 25 Albanians who served as great viziers' (prime ministers). ${ }^{105}$ The Albanians' third period under the Ottoman Empire, which began in the second half of the $19^{\text {th }}$ century, is the period generally covered in Albanian history books. Frashëri describes this period 'which was characterized by deep crises in the entire Ottoman Empire, but this time the dearest price was paid by Albanians. ${ }^{106}$ Frashëri states that since the Albanians had a privileged status within the Empire, they were the last to attempt to realize their golden age had come to an end, during the end of the $19^{\text {th }}$ century when the Albanians' neighbours were undergoing their own national renaissances. Frashëri states:

'the Albanians long were comrades of the Turks and not their slaves, but now they are suffering under great oppression and are being beaten and trampled underfoot more than the rest. If this be the case, why are the other nations endeavoring to throw off the heavy burden, while the Albanians are struggling to maintain it? Do they not see that they are leaning against a wall which is collapsing and which will crush and bury them? ${ }^{107}$

\section{Conclusion}

The issue of the Kosovar textbooks requires ongoing research and investigation into ongoing tensions between Kosovar and Turkish authorities. Why, for example, do Kosovo Albanian authors portray the Ottoman Empire in such a negative light, when it is known that the Albanians held high positions within the Ottoman Empire, and were even against an independent Albanian nation throughout the $19^{\text {th }}$ and early $20^{\text {th }}$

\footnotetext{
102 Ibid., p. 1.

103 Bilmez, B. (2003). "Shemseddin Sami Frashëri (1850-1904)": Contributing to the Construction of Albanian and Turkish Identities. Downloaded from: http://books.openedition.org/ceup/906, p. 341.

104 Frashëri, S. (1978). Shqipëria - Ç'ka qënë, ç'është e ç'do të bëhetë? Prishtinë, Rilindja, p. 34.

105 Ibid, p. 34

106 Ibid., p. 70-71.

107 Ibid., p. 70-71
} 
centuries? The anti-Ottoman Pan-Slavic ideology, which was ubiquitous in the Yugoslav education system, has evidently left a strong mark on the authors of textbooks used in Kosovo even today. Careful amendment of Kosovar historical texts is thus required. However advice and supervision by a professional body such as the Georg Eckert Institute rather than the Turkish government, would most likely lead to greater historical accuracy and improve relations between former nations in conflict, both at popular and at government level. 